\title{
The Food Bank Siswa Program in Addressing Food Insecurity, Healthy Diet and Food Poverty
}

Noorazlin Ramli, Fatimah Abd Ghani, Wan Nazriah Wan Nawawi, Malina Hanum Mohd Kamal, Abdul Wafi Abdul Rahman

To Link this Article: http://dx.doi.org/10.6007/IJARBSS/v11-i16/11235 DOI:10.6007/IJARBSS/v11-i16/11235

Received: 08 July 2021, Revised: 12 August 2021, Accepted: 26 August 2021

Published Online: 23 September 2021

In-Text Citation: (Ramli et al., 2021)

To Cite this Article: Ramli, N., Ghani, F. A., Nawawi, W. N. W., Kamal, M. H. M., \& Rahman, A. W. A. (2021). The Food Bank Siswa Program in Addressing Food Insecurity, Healthy Diet and Food Poverty. International Journal of Academic Research in Business and Social Sciences, 11(16), 292-303.

Copyright: (C) 2021 The Author(s)

Published by Human Resource Management Academic Research Society (www.hrmars.com)

This article is published under the Creative Commons Attribution (CC BY 4.0) license. Anyone may reproduce, distribute, translate and create derivative works of this article (for both commercial and non-commercial purposes), subject to full attribution to the original publication and authors. The full terms of this license may be seen at: http://creativecommons.org/licences/by/4.0/legalcode

Special Issue Title: Contemporary Issues in Tourism and Hospitality industry, 2021, Pg. 292 - 303 


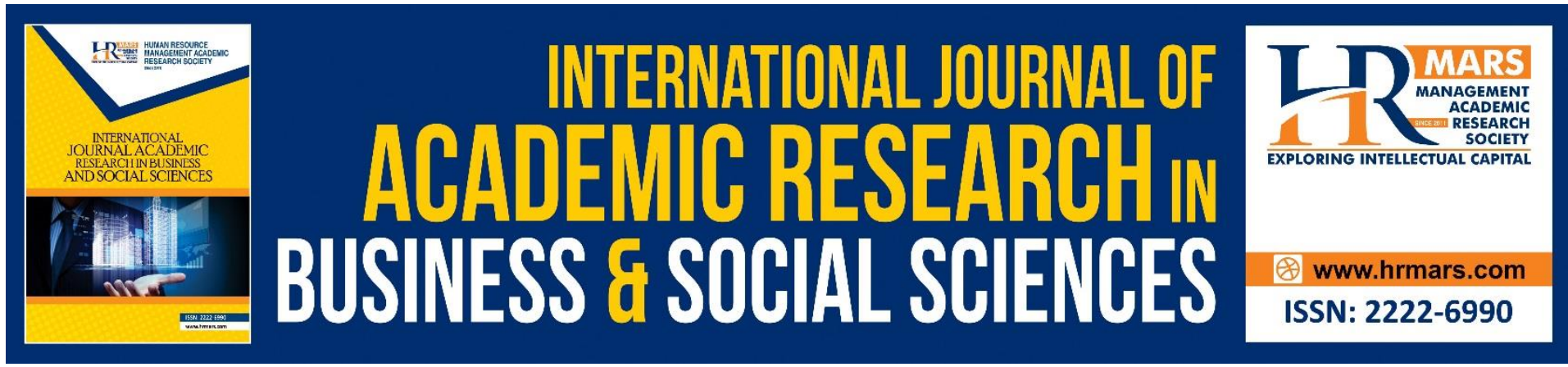

\title{
The Food Bank Siswa Program in Addressing Food Insecurity, Healthy Diet and Food Poverty
}

\author{
Noorazlin Ramli ${ }^{1}$, Fatimah Abd Ghani ${ }^{1}$, Wan Nazriah Wan \\ Nawawi ${ }^{1}$, Malina Hanum Mohd Kamal ${ }^{1}$, Abdul Wafi Abdul \\ Rahman $^{2}$ \\ ${ }^{1}$ Faculty of Hotel and Tourism Management, Universiti Teknologi MARA Cawangan \\ Terengganu Kampus Dungun, 23000 Dungun, Terengganu, ${ }^{2}$ Technical and Vocational \\ Education, Universiti Tun Hussein Onn Malaysia, 86400 Parit Raja, Batu Pahat, Johor \\ Email: noora115@uitm.edu.my
}

\begin{abstract}
The implementation of the Food Bank Siswa program is one of the strategies to eliminate hunger and food insecurity. This study was conducted to determine the effectiveness of the Food Bank Siswa program that has been implemented in Malaysia's public higher institutions and to ascertain the impact of the Food Bank Siswa program among B40 students in UTeM. A cluster sampling was used. The data from 52 respondents were obtained through online survey questionnaires and analyzed using SPSS software. The results indicated that the Food Bank Siswa program had the most prominent impact on food insecurity since most of the B40 students in UTeM were more satisfied with the role of the program in preventing food insufficiency. This study perhaps could help in spreading public awareness about this program among Malaysian citizens. Consequently, the government will become more proactive in strengthening the operation of the Food Bank Program in order to be more systematic. Finally, the Food Banks Siswa program have the potential to be implemented and expanded to all public and private universities in Malaysia as it provides useful insight that impact student's food security in supporting the government programs and plans; National Key Results Areas (NKRA) and Sustainable Development Goals (SDGs).
\end{abstract}

Keywords: Food Insecurity, Food Bank, B40, Food Poverty, Healthy Diet

\section{Introduction}

Food is a growing demand and acts as an important source for human's fundamental necessity for living, growing, and energy to perform daily operations (Martins et al., 2019). In fact, the right to food which is known as a basic human right provides continuous access to the resources necessary to produce, receive, and purchase adequate food, not only to prevent hunger but also to ensure health and well-being (FAO, 2019). In Maslow Hierarchy, food is considered as a basic human physiological need and it is very important for the survival and sustainability of mankind in society (Aruma \& Hanachor, 2017). To date, the accessibility of food and the capacity to acquire it can create access as one of the main components of food security. 
According to The State of Food Security and Nutrition in the World (FAO, 2019), food security is better known as the scenario in which all citizens have access to sufficient food, leading to a healthy and active life. However, due to poverty or other factors, not everyone is able to obtain food. Inability to obtain food indicates the dearth of food security, which lacks access to sufficient food physically, socially, and economically that may lead to hunger and lack of a good diet (Azdie et al., 2019). Therefore, in order to address the issue, other mechanisms are needed to assist those vulnerable groups. The food bank has emerged as a main reaction to the issue and acts as a mechanism to provide underprivileged people with access to food (Thompson et al., 2019; Middleton et al., 2017).

Generally, food banks refer to the associations that collect, store, pack and distribute food, and other necessities to those who need it; whether they cannot afford the food or are unable to reach the grocery store (Tarasuk et al., 2020). Additionally, food banks were initially intended as an emergency response that provides short-term food while waiting for assistance from the welfare state. They are a third-party organization, where local individuals and organizations donate food to those in need, stored locally and the local distribution network. Access to food bank services is managed through referrals from frontline service providers such as GPs, nurses, social workers, work center staff, and family support workers through food bank vouchers (Lambie-Mumford, 2018). Thus, various food bank programs have been introduced to tackle the hunger issue among the poor and needy (Sulaiman et al., 2021; Ukegbu et al., 2019 ; Bidisha et al., 2021).

\section{Problem in Context}

Food insecurity pays attention to vulnerable populations, especially those with low socioeconomic characteristics, living in poverty, and those who are living in remote areas. Vulnerable populations have higher rates of food insecurity and are unable to obtain adequate, safe, and nutritious food sources. In this context, unemployment is one of the factors contributing to food insecurity. Due to the unemployment and food shortages, the food bank program has been designed to help B40 groups in obtaining sufficient food supply. Cooperation between the government and NGOs in establishing a food bank has greatly helped 45,850 households to obtain food resources among the low-income group (B40) (Perimbanayagam, 2019).

Food poverty is also one of the causes of food insecurity among low-income households in Malaysia and university students from the B40 group. Studies showed that students associated with food poverty do not have access to adequate food and engage in unhealthy eating habits. Food insecurity and food poverty have the potential to negatively impact academic performance, health, and mental status (e.g., depression, stress, and anxiety) among university students (Ukegbu et al., 2019 ; Sulaiman et al., 2021). In addition, the lack of nutrition from food has many long-term consequences for health and well-being (Shahar et al., 2019). For children, food insecurity will result in poor physical and mental health, leading to long-term chronic health conditions, including diabetes, hypertension, heart disease, and depression (Nagata et al., 2019). The shortage of food can deprive the body of nutrients that it needs; for example, students need enough energy to be fully focused during learning. Therefore, university students can improve their physical well-being through this food bank program to focus more on academics (Manwa et al., 2019). 
In order to achieve the government's intention to ease the student's life and reduce food insecurity among university students in Malaysia, it is important to identify to what extent the effectiveness of the Food Bank Siswa Program that has been implemented in Malaysia's public higher institutions. Furthermore, it is crucial to ascertain on what are the impacts of the Food Bank Siswa Program on the students in public universities. Based on the literature, this research will highlight some of the impacts that are represented by food insecurity, healthy diet, and food poverty. Consequently, it is hoped that this study will help the government improve the program and help needy students.

\section{Literature Review}

In Malaysia, the development of Food Bank Malaysia has emerged from formal and informal channels run by non-government organizations (NGOs) or individuals from the existing food bank program commenced by the government in December 2018. The establishment of food banks in Malaysia was originally due to the increase of food waste that recorded approximately 8,000 tons or $60 \%$ of the food wasted every day (Kushairi, 2018) and to help the needy or hungry people in the B40 groups. A B40 (bottom 40\%) group is defined as a household income of less than RM 3,000. To some extent, the Malaysia Food Bank program is able to reduce the cost of living of underprivileged people and those in the low-income group (B40) in Malaysia (Isa et al., 2021).

\section{Food Bank}

Food banks are voluntary community organizations that solicit food and financial donations from the public and corporate sectors and locally distribute food assistance. At present, the Malaysian government has come out with a new idea of promoting a food bank program known as "Food Bank Siswa". The program is a continuation of the Malaysia National Food Bank Program to support B40 students in several public universities. The government aims to engage the low-income family students so that they can focus on learning and becoming better students. The Food Bank Siswa initiative aims to channel the surplus of food to students in need and at the same time, it could help alleviate the burden of living costs among students. Indirectly, the program has also managed to save a total of 2,120 metric tons of surplus food. A total of 12,251 students have benefited from this program conducted in 21 public universities (Ministry of Domestic Trades and Consumer Affairs, 2020).

\section{Food Insecurity}

To date, nearly a billion people worldwide have suffered from hunger due to the inability to obtain food, especially the people from low-income level. Additionally, since most of them no longer are able to cover the cost of living, this group often encounters deprivation problems due to food insecurity. Food insecurity can be defined as inadequate access to food due to inadequate and insecure household income, particularly short-term income losses (Tarasuk et al., 2020). According to Middleton et al. (2017), food banks have become the primary response to food insecurity in many high-income countries. Still, it has been said that they are not able to respond continuously and fully to the food requirements of those who use it. Miller et al. (2019) revealed a higher food insecurity rates (44.3\%) among university students and the majority of respondents (63\%) reported that they knew students other than themselves who, during the academic year, have problems with food insecurity or hunger. In line with that, the Food Bank program is one of the solutions to the food insufficiency and food insecurity issues worldwide including Malaysia. Thus, the implementation of the Food 
Bank Center is one of the measures to ensure people have access to food and to give a positive impact on the community (Hafizah et al., 2019).

\section{Healthy Diet}

The issue of a healthy diet among university students is not getting enough attention (Mukigi et al., 2018). Study data reported that the consumption of unhealthy diets exists among university students and is a hindrance to the well-being and success of students. Students' ability to excel in their academics is highly dependent on a healthy diet and this may be disrupted if the food intake period is discontinued (Ukegbu et al., 2019). Reports indicated that university students lack access to consistent, affordable, nutritious food and are engaging in unhealthy eating habits, which are barriers to making healthy food choices (Davidson \& Morrell, 2020). The issue of consuming an unhealthy diet resulting from food insecurity can negatively impact the academic performance, health, and mental status (e.g., depression, stress, and anxiety) of university students (Wan Azdie et al., 2019). Lack of food can lead to a lack of nutrients that the body needs, for example, students need enough energy to be fully focused during learning. Therefore, students can improve their physical well-being through this food bank program to focus more on academics (Manwa et al., 2019).

\section{Food Poverty}

The other factor that affects the implementation of the food bank program is food poverty. Food poverty can be defined as a situation when a household lacks resources to afford a nutritionally sufficient diet on a day-to-day basis (Bidisha et al., 2021). Consequently, the resulting poverty has led to food shortages among the poor group B40. Thus, the governmentsponsored food bank program helped reduce the B40's living cost while preventing food poverty. This is supported by evidence from Izwan et al. (2019) that approximately $22 \%$ of university students were food insecure and this result suggests that for every five university students, one will experience food insecurity related to food poverty. Besides, it was found that the "high cost of living" was the main contributor to food insecurity and food poverty among university students. In contrast, a study by Wan Azdie et al. (2019) reported that students face financial and economic difficulties so much that they may have interfered with their food intake. These factors clearly indicate that the students' food security and food poverty status are affected by their financial situation.

\section{B40}

According to Allang et al. (2019), B40 or Bottom 40 is the lowest income group in Malaysia with $40 \%$ of the population in Malaysia comprises the B40 population. The average household income is below RM 3,860. On the other hand, the Department of Statistics Malaysia (2017), stated that generally in Malaysia, B40 household income is not more than RM 4,630. Approximately, 2.7 million households were belonging to the B40 group in 2014. In 2018, the number increased as the government announced that 4.1 million households will continue to benefit from the Household Living Aid ) (BSH) which is specially allocated for the B40 group (Abu et al., 2020). In addition, the Malaysian government has expanded the access to higher education for the B40 group in an effort to reduce the socioeconomic gap and improve their living standards (Nor Samsiah et al., 2020). It was revealed that food insecurity among university students can affect their health because it is interconnected in many aspects of their life. Currently, this is an emerging threat for university students as it can affect their academic performances (Izwan et al., 2019). Thus, findings by Waity et al. (2020) encouraged the 
university to engage in a collaborative effort to create a food pantry or food bank in support of the students' well-being and positive academic outcomes.

\section{Methodology}

\section{Study Design, Location, and Sampling}

This study used quantitative measures in collecting a significant amount of data within the time frame. Thus, the questionnaire survey was adapted to evaluate the effectiveness of Food Bank Siswa program and the effects of the Food Bank Siswa program on the students of Universiti Teknikal Malaysia (UTeM). The questionnaires will determine the impact of the Food Bank Siswa program among B40 students who are qualified to receive the benefit. Generally, UTeM was targeted for the purpose of this study because UTeM has implemented a Food Bank Siswa assisted by the Student Representative Council or known as "Majlis Perwakilan Pelajar" (MPP). B40 students come from different family backgrounds, thus the online survey conducted by using a link from the internet platform allows them to assess the survey whenever possible due to the flexibility. A cluster sampling was used where a total of sixtyone (61) B40 students were identified as the target number of recipients.

\section{Research Instrument}

The questionnaire was designed in two versions: Malay and English because it is easier to understand by the respondents. There were four sections available in the questionnaire. The first was Section A which dealt with the respondents' demographic profile and was in the form of multiple choices. Next, Section B was about the satisfaction of the Food Bank Siswa program receivers towards the program. For Section $C$, the questions focused on the impact of the Food Bank Siswa program regarding food insecurity, healthy diet, and food poverty. Generally, all the questions in section $C$ were designed to measure the study's objectives, which were the impact of Food Bank Siswa program and the prominent impact of this program on the recipients. The Likert Scale was used as the indicator in this section with 1 as "strongly disagree," 2 as "disagree," 3 as "neutral," 4 as "agree", and 5 as "strongly agree." Finally, openended questions were constructed to study the recommendation from the respondents in order to improve the level of Food Bank Siswa's services in Section D. The level of Cronbach's alpha for section $B$, the satisfaction of receivers, was good with 0.705 and section $C$, the impact of Food Bank Siswa, was at 0.977.

\section{Statistical Analysis}

The analysis is about bringing thoughts into an action plan to ensure the question is answered and the data collection instrument receives the information as targeted by the researchers. Before interpreting data, the researchers must draw up a data analysis plan which is in line with the aim and goal of completing this study. The questionnaire was distributed online to all sixty-one (61) B40 students. Consequently, only fifty-two (52) samples were returned. All the data were collected and analyzed using SPSS software.

\section{Results and Analysis Demographic Profiles}

A total of fifty-two (52) respondents with $85 \%$ response rate was collected within the data collection time frame. All the data were collected through online survey questionnaires using Google Forms. The majority of the respondents were males (32 respondents, 61.5\%) and 20 (38.5\%) females. Most of the respondents (51 respondents, $98.1 \%$ ) were between the age of 
18 to 25 years old and only one (1) respondent was between 26-29 years old. Moreover, 34 respondents $(65.4 \%)$ were diploma students from various faculties and the remaining 17 (32.7\%) and one (1.9\%) were degree and master's students. All the respondents were in the B40 group, which means that their family's income level is below RM 3,860.

Table 1: Demographic Profile based on Frequency and Percentage

\begin{tabular}{|c|c|c|c|}
\hline Variable & & $\begin{array}{l}\text { Frequency } \\
\text { (N) }\end{array}$ & $\begin{array}{l}\text { Percentage } \\
\text { (\%) }\end{array}$ \\
\hline \multirow[t]{2}{*}{ Gender } & Male & 32 & 61.5 \\
\hline & Female & 20 & 38.5 \\
\hline \multirow[t]{4}{*}{ Age (Year) } & $18-21$ & 34 & 65.4 \\
\hline & $22-25$ & 17 & 32.7 \\
\hline & $26-29$ & 1 & 1.9 \\
\hline & 29 above & - & - \\
\hline \multirow[t]{5}{*}{ Education Level } & Pre-Diploma & - & - \\
\hline & Diploma & 34 & 65.4 \\
\hline & Degree & 17 & 32.7 \\
\hline & Master's & 1 & 1.9 \\
\hline & PhD & - & - \\
\hline \multirow[t]{4}{*}{ Family Income (RM) } & $0-1000$ & 19 & 36.5 \\
\hline & $1001-2000$ & 31 & 59.6 \\
\hline & $2001-3000$ & 2 & 3.8 \\
\hline & 3000 above & - & - \\
\hline \multirow[t]{13}{*}{ Faculty } & Faculty of Electronics and Computer & 7 & 13.5 \\
\hline & Engineering & 4 & 7.7 \\
\hline & Faculty of Electrical Engineering & 9 & 17.3 \\
\hline & Faculty of Mechanical Engineering & 6 & 11.5 \\
\hline & Faculty of Manufacturing & & \\
\hline & Engineering & 11 & 21.2 \\
\hline & Faculty of Information and & & \\
\hline & Communications Technology & 4 & 7.7 \\
\hline & $\begin{array}{l}\text { Faculty of Technology Management } \\
\text { and Technopreneurship } \\
\text { Faculty of Electrical and Electronic }\end{array}$ & 5 & 9.6 \\
\hline & Engineering Technology & 6 & 11.5 \\
\hline & Faculty of Mechanical and & & \\
\hline & Manufacturing Engineering & & \\
\hline & Technology & & \\
\hline
\end{tabular}

Aligned with the data from MPP, the authors expected that more male respondents would participate compared to female respondents. Besides, the courses provided by UTeM are mostly technical courses that are most suitable for males to learn rather than females. The data collection focused on the receivers of the Food Bank Siswa Program. Additionally, most of the respondents were between 18 and 21 years old. This result was expected as the majority of UTeM students who answered the questionnaires were Diploma students. Thus, this result also explains why most of the respondents had a diploma education level from various faculties. 
Role of Food Bank in Addressing Food Insecurity, Providing Healthy Diet, and Preventing Food Poverty

Table 2 presents an analysis of the mean scores of the respondents regarding the impact of Food Bank Siswa on food insecurity, healthy diet, and food poverty.

Table 2: Role of Food Bank in Addressing Food Insecurity, providing Healthy Diet and prevent Food Poverty

\begin{tabular}{|c|c|c|c|}
\hline & & Mean & $\begin{array}{l}\text { Std. } \\
\text { Deviation }\end{array}$ \\
\hline \multirow[t]{5}{*}{$\begin{array}{l}\text { Food } \\
\text { Insecurity }\end{array}$} & $\begin{array}{l}\text { The Food Bank Siswa program has helped me face } \\
\text { food insufficiency }\end{array}$ & 4.77 & .546 \\
\hline & $\begin{array}{l}\text { I am no longer reducing my food portions because } \\
\text { of the Food Bank Siswa program }\end{array}$ & 4.19 & .687 \\
\hline & $\begin{array}{l}\text { My mealtime has become consistent after the Food } \\
\text { Bank Siswa program was established }\end{array}$ & 4.25 & .519 \\
\hline & $\begin{array}{l}\text { The Food Bank Siswa program has prevented other } \\
\text { students and I from going hungry }\end{array}$ & 4.75 & .437 \\
\hline & $\begin{array}{l}\text { My friends and I are no longer holding on to hunger. } \\
\text { We do not need to save money for food because of } \\
\text { the Food Bank Siswa program }\end{array}$ & 4.54 & .609 \\
\hline \multirow[t]{5}{*}{ Healthy Diet } & $\begin{array}{l}\text { The Food Bank Siswa program provides a balanced } \\
\text { meal for my friends and I }\end{array}$ & 4.19 & .627 \\
\hline & $\begin{array}{l}\text { The Food Bank Siswa program has helped us to not } \\
\text { skip our meals }\end{array}$ & 4.31 & .673 \\
\hline & $\begin{array}{l}\text { I feel energized and focused during my studies } \\
\text { because of the Food Bank Siswa program }\end{array}$ & 4.29 & .637 \\
\hline & $\begin{array}{l}\text { The Food Bank Siswa program provides me with } \\
\text { adequate amount of nourishing food }\end{array}$ & 4.19 & .525 \\
\hline & $\begin{array}{l}\text { I no longer skip my breakfast because I can get my } \\
\text { food from the Food Bank Siswa program }\end{array}$ & 4.56 & .752 \\
\hline \multirow[t]{5}{*}{$\begin{array}{l}\text { Food } \\
\text { Poverty }\end{array}$} & $\begin{array}{l}\text { Food Bank Siswa program has helped me improve } \\
\text { my economic status at university }\end{array}$ & 4.19 & .658 \\
\hline & $\begin{array}{l}\text { This program allows my friends and I to enjoy meals } \\
\text { without doubting the quality of the food }\end{array}$ & 4.52 & .641 \\
\hline & $\begin{array}{l}\text { I have been using my money for my studies without } \\
\text { having to think about the hunger that I faced before }\end{array}$ & 4.33 & .648 \\
\hline & $\begin{array}{l}\text { The Food Bank Siswa program helps me manage my } \\
\text { finances properly }\end{array}$ & 4.25 & .622 \\
\hline & $\begin{array}{l}\text { The Food Bank Siswa program has given me the } \\
\text { ability to obtain food }\end{array}$ & 4.73 & .490 \\
\hline
\end{tabular}

Note: $p>.05$

The Prominent Impact of the Food Bank Program for Students in Higher Education Institutions

Table 3 shows the three different elements on the impact of Food Bank Siswa that obtained the highest mean scores. 
Table 3: A Comparison of the Impact of Food Bank Siswa based on Mean Score

\begin{tabular}{ll}
\hline Element & Mean \\
\hline Food Insecurity: The Food Bank Siswa program has helped me face 4.77 \\
food insufficiency \\
Healthy Diet: I am no longer skipping my breakfast because I get my 4.56 \\
food from the Food Bank Siswa program \\
Food Poverty: The Food Bank Siswa program has given me the ability 4.73 \\
to obtain food
\end{tabular}

This study aimed to determine the effectiveness of the Food Bank Siswa program that has been implemented in Malaysia's public higher institutions and to ascertain the impact of the Food Bank Siswa program among B40 students in UTeM. The data analysis and result have indicated the highest mean score results based on three items from each of the impact of Food Bank Siswa program among UTeM B40 students. For impact on food insecurity, the highest mean score is 4.77 and was contributed from item number one which is "The Food Bank Siswa program helps me face food insufficiency". This result indicated that the program had the most prominent impact on food insecurity because the B40 students in UTeM were more satisfied with the role of the Food Bank Siswa program in preventing food insufficiency. It is supported by Tarasuk et al (2020), who discovered that food banks were the only source of immediate assistance for households struggling to meet food needs and to control food insufficiency. Therefore, the Food Bank Siswa program had the most impact on alleviating the food insecurity faced by UTeM B40 students, especially in reducing food insufficiency.

Additionally, the mean score for the second impact, healthy diet, indicated a result of 4.56, contributed by item number five, "I no longer skip my breakfast because I get my food supply from the Food Bank Siswa program." This result revealed that the respondents no longer had to skip breakfast because they could get their food supply from the Food Bank Siswa program. Since the students can directly eat the food given by the program, they are able to build up their good eating habit. This is supported by Davidson and Morrell (2020) who highlighted good eating habits as part of a healthy diet from an early age.

Moreover, the Food Bank Siswa program showed a mean score of 4.73 towards food poverty for the last impact. It is represented by item number five that highlighted "The Food Bank Siswa program has given me the ability to obtain food" showed that most of the respondents strongly agree that the Food Bank Siswa program had given them the ability to obtain food. The study by Vissing et al. (2017) supported the statement by highlighting how food bank organizations implement food pantry programs in providing food services based on social responsibility for the community in helping the less fortunate people. This will somehow reduce food poverty and the number of students who are unable to afford adequate food. Thus, the overall findings and the results of the analyses above supported the objectives of this research.

\section{Conclusion}

In conclusion, this study proves that the implementation of the Food Bank Siswa program, which was implemented in selected university, had shown significant positive impacts among the students. The main objectives of this research were to identify the effectiveness of the Food Bank Siswa program that has been implemented in University Teknikal Malaysia (UTeM). 
This study also highlighted the impact of the Food Bank Siswa program among B40 students in the university. Based on past literature, the impact of the food bank program includes preventing food insecurity, providing a healthy diet, and alleviating food poverty. Based on the analysis, the results revealed that the effectiveness of the Food Bank Siswa program has contributed to the prevention of food insecurity, providing healthy eating, and alleviating food poverty among UTeM's B40 students. Out of all the impacts, this research found that the program had the most dominant impact on food insecurity, indicating that food shortage is a major factor that led to the emergence of these food bank programs, especially in UTeM. This is because the results proved that the Food Bank Siswa program has helped students overcome food insufficiency. As a result, the food bank programs implemented by the government have been effective in increasing engagement with students who come from lowincome family, so they can focus better in their studies and become better students. Furthermore, the Food Bank Siswa program is beneficial in helping needy students.

In addition, the Food Bank Siswa program has also helped the government in improving the B40 economy, in line with the government policies based on the National Key Results Areas (NKRA) and Sustainable Development Goals (SDGs). Besides, the government can now improve the student outcomes, as commanded by the Minister of Education, and elevate the standard of living among low-income households. Moreover, the program can help fulfill the government policy in giving the students basic needs such as food to focus on studying without worrying about the food expenses. Finally, as a recommendation, the Food Banks Siswa program can be implemented and expanded to all public and private universities in Malaysia based on the effectiveness and positive impacts, as it has been proven to help B40 students.

\section{Acknowledgement}

We would like to express our sincere appreciation and deep gratitude to all B40 students in UTeM for their support and willingness to spend some time to fill in the questionnaire. In addition, a gratitude to UITMCTKD in encourage us for completing this study.

\section{Corresponding Author}

Noorazlin Ramli. Faculty of Hotel and Tourism Management, Universiti Teknologi MARA Cawangan Terengganu Kampus Dungun.

Email: noora115@uitm.edu.my

\section{References}

Abu, R., Hamdan, R., \& Sani, N. S. (2020). Ensemble Learning for Multidimensional Poverty Classification. Sains Malaysiana, 49(2), 447-459.

Allang, B. A., Mahzan, M. A., Abdul Razaq, A., \& Anuar, A. (2019). Influenced Factors of B40 Students' Academic Achievement. Global Conferences Series: Social Sciences, Education and Humanities (GCSSSEH).

Aruma, E. O., \& Hanachor, M. E. (2017). Abraham Maslow's Hierarchy of Needs and Assessment of Needs in Community Development. International Journal of Development and Economic Sustainability, 5 (7). 15-27.

Bidisha, S. H., Mahmood, T., \& Hossain, M. B. (2021) Assessing Food Poverty, Vulnerability and Food Consumption Inequality in the Context of COVID-19: A Case of Bangladesh. International Journal of Legal Medicine. doi: 10.1007/s11205-020-02596-1. 
Davidson, A. R., \& Morrell, J. S. (2020). Food insecurity prevalence among university students in New Hampshire. Journal of Hunger \& Environmental Nutrition, 15 (1), 118-127.

Department of Statistics Malaysia. (2017). Household income estimates and incidence of poverty report, Malaysia, 2018. Retrieved from https://www.dosm.gov.my

FAO. (2019). The State of Food Security and Nutrition in the World. Retrieved September 9, 2019, from http://www.fao.org/state-of-food-security-nutrition/en/.

Hafizah, Z., Faisal, M., \& Zakaria, O. (2019). Zero Hunger and Sustainable Development Goals: Model of Food Bank Centre by Lembaga Zakat Negeri Kedah. International Journal of Islamic and Civilizational Studies, 6(2), 85- 90.

Isa, K., Jamin, J., Suhaimy, K. A., Jaes, L., Damin, Z. A., Abdullah, M. H. A., Saleh, N. S., Palpanadan, S. T. (2021). The Awareness and Implementation of Foodbank Program in Malaysian University. Turkish Journal of Computer and Mathematics Education. 12 (2). 581- 587.

Izwan, S. R., Asma' A., Nurzalinda Z., Rahijan A. W., \& Afifah, S. N. J. (2019). Food Insecurity Among University Students at Two Selected Public Universities in Malaysia. Malays. Appl. Biol. (2019) 48(1), 101-110.

Kushairi, A. (2018). Food for thought. Retrieved from https://www.nst.com.my/opinion/columnists/2018/08/404704/food-thought.

Lambie-Mumford, H. (2018). The growth of food banks in Britain and what they mean for social policy. Critical Social Policy, 39 (1), 3-22.

Manwa, L., Manwa, L., \& Mudekunye, J. (2019). Living conditions and upkeep as antecedents related to academic performance of Zimbabwean female students in Masvingo tertiary institutions.

Martins, C., Melo, M., \& Pato, M. (2019). Redesigning a food bank supply chain network in a triple bottom line context. International Journal of Production Economics, 214, 234-247. doi: 10.1016/j.ijpe.2018.11.011

Middleton, G., Mehta, K., McNaughton, D., \& Booth, S. (2018). The experiences and perceptions of food banks amongst users in high-income countries: An international scoping review. Appetite, 120, 698-708.

Miller, M., Middendorf, G., Wood, S., Sonya, L., Scott, J., \& Brian, L. (2019). Food Insecurity and Assistance on Campus: A Survey of the Student Body. Online Journal of Rural Research \& Policy. 14(2).

Ministry of Domestic Trades and Consumer Affairs. (2020). Program Foodbank Siswa 2020. Retrieved from https://www.kpdnhep.gov.my/en/media-kpdnhep/beritakpdnhep/berita-terkini/2020/568-program-foodbank-siswa-2020.html.

Mukigi, D., Thornton, K., Binion, A., Brown, K., Church, M., Cook, M., ... \& Brown, O. (2018). Food insecurity among college students: an exploratory study. Journal of Nutrition and Health Sciences, 5(1), 106.

Nagata, J. M., Palar, K., Gooding, H. C., Garber, A. K., Domingo, K. B., \& Weiser, S. D. (2019). Food Insecurity and Chronic Disease in US Young Adults: Findings from the National Longitudinal Study of Adolescent to Adult Health. J Gen Intern Med, 34(12). 2756-62.

Samsiah, N. S., Fikri, A. M. N., Zulaiha, A. O., Zakree, M. A. N., \& Nadiyah, K. M. (2020). DropOut Prediction in Higher Education Among B40 Students (IJACSA) International Journal of Advanced Computer Science and Applications, 11(11), 55-559.

Perimbanayagam, K. (2019). Food Bank Malaysia a success [NSTTV]. Retrieved September 16, 2019, from https://www.nst.com.my/news/nation/2019/03/474624/food-bankmalaysia-success-nsttv. 
Shahar, S., Lau, H., Puteh, S. E. W., Amara, S., Razak, N. A. (2019). Health, access and nutritional issues among low-income population in Malaysia: introductory note. BMC Public Health, 19(4). 552.

Sulaiman, N., Yeatman, H., Russell, J., \& Law, L. S. (2021). A Food Insecurity Systematic Review: Experience from Malaysia. Nutrients 2021, 13. 945. https://doi.org/ 10.3390/nu13030945.

Tarasuk, V., Fafard St-Germain, A. A., \& Loopstra, R. (2020). The Relationship Between Food Banks and Food Insecurity: Insights from Canada. VOLUNTAS: International Journal of Voluntary and Nonprofit Organizations, 31, 841-852.

Thompson, C., Smith, D., \& Cummins, S. (2019). Food Banking and Emergency Food Aid: Expanding the Definition of Local Food Environments And Systems. Int J Behav Nutr Phys Act, 16 (2).

Ukegbu, P., Nwofia, B., Ndudiri, U., Uwakwe, N., \& Uwaegbute, A. (2019). Food Insecurity and Associated Factors Among University Students. Food and Nutritional Bulletin, 40, 271281.

Vissing, Y., Gu, J., Jones, A., \& Gabriel, S. (2017). Preserving Dignity in the Face of Hunger. Humanity \& Society, 41(4), 461-481.

Waity, J. F., Huelskamp, A., \& Russell, J. (2020). Collaborating to Assess and Address Food Insecurity on a College Campus: A Case Study at a Mid-Sized, Regional University. Innov High Educ, 45, 405-417.

Azdie, W. M. A. B., Shahidah, I., Suriati, S., \& Rozlin, A. R. (2019). Prevalence and factors affecting food insecurity among university students in Pahang, Malaysia. Malaysian Journal of Nutrition, 25 (1). 59-67. 